\title{
Soil fertility beneath the crown of tree species submitted to planting densities
}

\author{
Patrícia L. de O. F. Siqueira ${ }^{1}$, Paulo S. L. e Silva ${ }^{2}$, Kadson E. F. Silva ${ }^{3}$, \\ Vianney R. de Oliveira ${ }^{4}$, Iron M. Dantas ${ }^{5} \&$ Fábio H. T. de Oliveira ${ }^{6}$
}

\author{
${ }^{1}$ UFERSA. Mossoró, RN. E-mail: patricia_liany@hotmail.com (Autor correspondente) \\ ${ }^{2}$ UFERSA. Mossoró, RN. E-mail: paulosergio@ufersa.edu.br \\ ${ }^{3}$ UFC. Fortaleza, CE. E-mail: k-dson@hotmail.com \\ ${ }^{4}$ UFERSA. Mossoró, RN. E-mail: vianney.reinaldo@hotmail.com \\ ${ }^{5}$ UERN. Mossoró, RN. E-mail: irondantas@gmail.com \\ ${ }^{6}$ UFERSA. Mossoró, RN. E-mail: fabio@ufersa edu.br
}

\section{Key words:}

litter

Mimosa caesalpiniifolia

Gliricidia sepium

\begin{abstract}
A B S T R A C T
The aim of this study was to evaluate the nutrient content of leaf litter and the soil beneath the crown of gliricidia (Gliricidia sepium) and sabiá (Mimosa caesalpiinifolia) under different planting densities $(400,600,800,1000$ and 1200 plants $^{-1} \mathrm{a}^{-1}$. The experiment was carried out in a randomized block in split plot design, with three replications. The species were assigned to the plots and the densities to the subplots. Samples of litter and soil were collected three years after the trees were planted and submitted for chemical analysis. The Mg content in the litter from the gliricidia was higher than that from the sabiá. There was no difference between the species as to the other elements. The increase in planting density reduced the levels of $\mathrm{N}$ and $\mathrm{Mg}$, but did not alter the levels of $\mathrm{Ca}$ and $\mathrm{P}$ in the litter. The nutrient content in the litter from both species presented the sequence $\mathrm{Ca}>\mathrm{N}>\mathrm{Mg}>\mathrm{K}>\mathrm{P}$. There was no difference in soil fertility between soils planted with both species. An increase in density resulted in an increase in the levels of $\mathrm{P}$ and $\mathrm{Mg}$ in the soil. The contents of $\mathrm{Na}$ and $\mathrm{Ca}$ first increased and then decreased with the increase in density. The density had no effect on organic matter, $\mathrm{K}, \mathrm{pH}$ or the potential acidity.
\end{abstract}

Palavras-chave:

serapilheira

Mimosa caesalpiniifolia

Gliricidia sepium

\section{Fertilidade do solo sob a copa de espécies arbóreas submetidas a densidades de plantio}

\begin{abstract}
R E S U M O
Objetivou-se, neste trabalho, avaliar os teores de nutrientes da serapilheira e do solo sob a copa da gliricidia (Gliricidia sepium) e sabiá (Mimosa caesalpiinifolia) em densidades de plantio (400, 600, 800, 1000 e 1200 plantas $\left.\mathrm{ha}^{-1}\right)$. O experimento foi realizado em blocos ao acaso com três repetições em parcelas subdivididas. As espécies foram aplicadas nas parcelas e as densidades nas subparcelas. As amostras da serapilheira e do solo foram coletadas três anos após o plantio das árvores e submetidas às análises químicas. O teor de $\mathrm{Mg}$ na serapilheira da gliricidia foi superior ao da sabiá. Não houve diferença entre espécies quanto aos demais elementos. O aumento da densidade de plantio diminuiu os teores de $\mathrm{N}$ e $\mathrm{Mg}$ mas não alterou os teores de Ca e P, na serapilheira. As quantidades dos teores dos nutrientes na serapilheira das duas espécies apresentaram a sequência $\mathrm{Ca}>\mathrm{N}>\mathrm{Mg}>\mathrm{K}>\mathrm{P}$. Não ocorreu diferença entre solos cultivados com as duas espécies na fertilidade do solo. $\mathrm{O}$ aumento da densidade aumentou os teores de $\mathrm{P}$ e $\mathrm{Mg}$ no solo. Os teores de $\mathrm{Ca}$ e $\mathrm{Na}$ aumentaram e depois diminuíram com o aumento da densidade. Não se constatou efeito de densidade na matéria orgânica, K, pH nem na acidez potencial.
\end{abstract}

\section{INTRODUCTION}

The Caatinga, a semiarid ecoregion which is unique in the world (Casteleti et al., 2003), covers a significant area of Brazil, and is considered to be the main ecosystem in the northeast of the country. It is probably the biome which is most threatened and transformed by human action, and is now in a process of acute degradation. The inadequate management of herds, abandoning of areas once used for cultivation, extraction of firewood to meet the demands of brickyards and potteries, and mining all degrade the 'Caatinga' to different extents (Galindo et al., 2008). Approximately $40,000 \mathrm{~km}^{2}$ of the North-eastern region have become desert in the last 15 years due to man's interference (Pereira, 2010).

The planting of forest species which improve the properties of the soil with deposits of leaf litter is a possibility that reconciles economic benefits and sustainability (Mendonça et al., 2008). The act of revegetation starts this reclamation of degraded areas. The maintenance and protection of these areas enable completion of the reclamation process. 
Reclamation of these degraded areas must take into account the components of the soil-plant-atmosphere system, seeking an integrated recovery of all the biological processes. The soil must be addressed regarding its physical, biological and chemical aspects. The plants used in the recovery process must be understood in various aspects including botanical, physiological and interaction with animals. Knowledge of the atmosphere in the reclamation of degraded areas also depends on several aspects, including climatology and environmental physics (Duarte \& Casagrande, 2006).

With regard to the chemical aspects of the soil in the reclamation of degraded areas, two of the most relevant aspects are the species to be cultivated and the planting density of these species. This is because several studies (Mallik et al., 2008) have demonstrated that different plant species affect the properties of the soil differently. Accordingly, leguminous plants are worthy of consideration when reclaiming degraded areas. Revegetation with legumes in these areas, adds large amounts of organic matter and $\mathrm{N}$ in a relatively short time through the production of leaf litter, favoring the cycling of nutrients and the recovery process (Costa et al., 2004). On the other hand, several authors have shown that the planting density of perennial crops can influence soil fertility (Pavan et al., 1999; Rangel et al., 2008).

With the objective of evaluating the behaviour of sabiá (Mimosa caesalpiniifolia Benth.) and gliricidia [Gliricidia sepium (Jacq) Kunth ex Walp.] under semi-arid conditions, and with a view to the reclamation of degraded areas in the region, an experiment was set up in 2008. The two species were planted at five densities. The objective of the present work was to evaluate the fertility of the soil under the tree canopy of the above experiment, three years after planting.

\section{Material ANd Methods}

The experiment was carried out at the Rafael Fernandes Experimental Farm of the Federal Rural University of the Semiarid (UFERSA), $20 \mathrm{~km}$ away from the town of Mossoró ( $5^{\circ} 11^{\prime} \mathrm{S}, 37^{\circ} 20^{\prime} \mathrm{W}$, at an altitude of $18 \mathrm{~m}$ ). According to the Köppen classification, the bioclimate in the region is Bswh, i.e. hot, with higher precipitation towards autumn. The region has a maximum average air temperature of between 32.1 and 34.5 ${ }^{\circ} \mathrm{C}$ and a minimum average between 21.3 and $23.7^{\circ} \mathrm{C}$, with June and July being the coldest months. The mean annual rainfall is around $825 \mathrm{~mm}$ (Carmo Filho \& Oliveira, 1989).

The soil in the experiment area is classified as a Red-Yellow Argisol, according to the Brazilian Soil Classification System (EMBRAPA, 2006). The analysis of a soil sample from the experimental area showed: $\mathrm{pH}=6.8 ; \mathrm{Ca}^{2+}=1.80 \mathrm{cmol}_{\mathrm{c}} \mathrm{dm}^{-3}$; $\mathrm{Mg}^{2+}=0.40 \mathrm{cmol}_{\mathrm{c}} \mathrm{dm}^{-3}, \mathrm{~K}^{+}=0.10 \mathrm{cmol}_{\mathrm{c}} \mathrm{dm}^{-3} ; \mathrm{Na}^{+}=0.01 \mathrm{cmol}_{\mathrm{c}}$ $\mathrm{dm}^{-3} ; \mathrm{Al}^{3+}=0.00 \mathrm{cmol}_{\mathrm{c}} \mathrm{dm}^{-3} ; \mathrm{P}=25 \mathrm{mg} \mathrm{dm}^{-3}$; organic matter $=1.90 \mathrm{~g} \mathrm{~kg}^{-1}$.

The sabiá seeds were obtained from natural populations in Mossoró, and those of gliricidia from the Advisory Services for Projects in Alternative Agriculture [Assessoria e Serviços a Projetos em Agricultura Alternativa (AS-PTA)], a nongovernmental organization with an office in Campina Grande, in the state of Paraíba. They were planted in January of 2008 in black plastic bags. The bags were filled with a substrate comprised of $1 / 3$ manure and $2 / 3$ soil. Transplanting was done in April 2008, to the experimental area of virgin land which had been cleared manually. The seedlings were transplanted into $60 \times 60 \times 60 \mathrm{~cm}$ pits. The pits were fertilized with $18 \mathrm{~L}$ of cattle manure.

The two species were planted at the following planting densities (plants ha-1): 400 (at a spacing of $5.0 \times 5.0 \mathrm{~m}), 600(4.0$ x $4.0 \mathrm{~m}), 800(4.0 \times 3.0 \mathrm{~m}), 1,000(4.0 \times 2.3 \mathrm{~m})$ and 1,200 (3.0 $\mathrm{x} 2.6 \mathrm{~m}$ ). A randomized complete block design was used with three replications and split plots. The species were assigned to the plots and planting density to the subplots.

The litter and soil were collected for chemical analysis in April 2011. To collect the litter, a frame, 0.6 x $0.6 \mathrm{~m}$, was thrown at random into the middle of each subplot, so as to mark the sample area. The collected material was homogenized for the chemical analysis.

The soil was collected between the plants of the central row of each subplot. With the use of a manual post hole digger three soil samples were collected, spaced $0.5,1.0$ and $1.5 \mathrm{~m}$ on either side of the stems of the two central plants in each subplot. The samples were collected at a depth of $0-10 \mathrm{~cm}$ and mixed. The composite sample was therefore made up of 12 single samples. The composite sample was homogenized and two subsamples were subjected to analysis.

The litter samples were analysed for levels of N, P, K, Ca and $\mathrm{Mg}$ in the Soil Chemistry and Fertility Laboratory of UFERSA. The composite soil samples were taken to the same laboratory, air-dried and passed through sieves of $2 \mathrm{~mm}$, placed in suitable plastic containers and analysed for $\mathrm{P}, \mathrm{Na}, \mathrm{K}$, organic matter, $\mathrm{Ca}$, $\mathrm{Mg}, \mathrm{H}+\mathrm{Al}$ (potential acidity) and $\mathrm{pH}$ in water, as outlined in the manual of methods for soil analysis (EMBRAPA, 1997).

The mean of the data from the two subsamples of soil, and the data from the litter samples were subjected to variance analysis, carried out using the SISVAR software version 5.3. and the means of the treatments were compared by the Tukey test at 0.05 level of probability. The data relating to planting density were subjected to variance and regression analyses. The regression equations were chosen based on the following criteria: biological explanation of the phenomenon, the simplicity of the equation, and testing the parameters of the equation by Student's t-test at probability level of 0.1 .

\section{Results AND Discussion}

The effect of species was only significant for magnesium content. For potassium content, there was effect of species $\mathrm{x}$ planting densities interaction. The magnesium content of the litter under the gliricidia crown was higher than that of the sabiá (Table 1).

Although variance analysis did not show any effect of planting density on the potassium content, regression analysis did. The increase in planting density produced an increase in the potassium content of the gliricidia leaf litter, but did not alter its content in the litter under sabiá (Table 2). The maximum $\mathrm{K}$ 
Table 1. Mean nutrient content (for three replications and five planting densities) in the litter of tree species at three years of age

\begin{tabular}{lcccc}
\hline \multirow{2}{*}{ Species } & \multicolumn{4}{c}{ Nutrients ${\left.\mathbf{~ ( ~} \mathbf{~ k g}^{-1}\right)}$} \\
\cline { 2 - 5 } & $\mathbf{N}$ & $\mathbf{P}$ & $\mathbf{C a}$ & $\mathbf{M g}$ \\
Gliricidia & $7.94 \mathrm{a}$ & $0.21 \mathrm{a}$ & $31.17 \mathrm{a}$ & $5.55 \mathrm{a}$ \\
Sabiá & $9.55 \mathrm{a}$ & $0.33 \mathrm{a}$ & $34.33 \mathrm{a}$ & $2.71 \mathrm{~b}$ \\
\hline
\end{tabular}

Averages followed by the same letter do not differ between themselves by the Tukey test at 0.10 probability

content in the gliricidia litter occurred at a planting density of approximately 1,017 plants ha-1. At the two lower planting densities, the sabiá was superior to the gliricidia for potassium content, but at the density of 1,000 plants $\mathrm{ha}^{-1}$ the opposite occurred (Table 2).

It can be argued that an increase in planting density should decrease the level of most nutrients. This perhaps does not occur as this reduction depends on the nutrient availability in the soil. An increase in planting density can improve the chemical quality of the soil through better erosion control, a higher input of leaf litter (Costa et al., 2004) and nutrient cycling (Pavan et al., 1999). Pavan et al. (1999) found that an increase in planting density in the coffee tree, resulted in an improvement in the characteristics of the soil.

Species respond differently to increases in planting density. Some are more tolerant than others to compete (Mallik et al., 2008), and this is reflected in the concentration of nutrients in the leaves. In this respect it should be mentioned that in the experiment on which the present study is based, it was seen that the gliricidia plants presented on average 4.4 branches per stem, counting from the base of the stem, while the average number of branches for the sabiá was only 2.45 per stem. These averages suggest a greater tolerance of sabiá to increases in planting density, and consequently differences in the nutrient content of the leaves.

Moreover, the species differ in the amount of litter produced and in the rates of decomposition of that litter (Vivanco \& Austin, 2008) and should therefore have a different influence on the soil in which they vegetate, and respond differently to these changes. Differences in tolerance due to increased planting density and to changes in the soil may therefore explain the differences in the foliar nutrients of the leaf litter from sabiá and gliricidia (Table 2).

Regression analysis showed the effects of planting density on the nitrogen and magnesium contents. An increase in planting density decreased the contents of the two elements in the leaf litter from both species (Table 3 ). The phosphorus and calcium contents were not affected by planting density (Table 3 ).

Concentrations of these nutrients analysed in the litter from both species presented the following sequence: $\mathrm{Ca}>\mathrm{N}>\mathrm{Mg}$ $>\mathrm{K}>$ P. Similar data were obtained by other authors (Vieira et al., 2010). Among the various authors who have studied the problem, differences, when they occur (and they are usually of low magnitude), happen if $\mathrm{Ca}$ (or $\mathrm{N}$ ) is the most abundant, followed by $\mathrm{Mg}$ (or K) and finally P (or S). Leite et al. (2011) were the only authors to check a discordant sequence (Table 4). Calcium enrichment in the leaf litter may be due to a slower release of this element by the newly-fallen material which makes up the litter (Vieira et al., 2010). According to Vezzani et al. (2001), phosphorus concentrations in plant tissue are very low compared to the other nutrients, indicating little potential for the cycling of this element.

Variance analysis showed no effects of species or the species $\mathrm{x}$ planting densities interaction for those characteristics analysed in the soil. The averages of the characteristics of the soil cultivated with gliricidia and sabiá are presented in Table 4.

Regression analysis showed the effects of planting density on the contents of $\mathrm{P}, \mathrm{Ca}, \mathrm{Mg}$ and $\mathrm{Na}$ in soil (Table 5). The $\mathrm{P}$ and $\mathrm{Mg}$ increased continuously as the $\mathrm{Ca}$ and $\mathrm{Na}$ increased, but then

Table 4. Mean concentrations of soil nutrients under the crown of tree species at three years of age

\begin{tabular}{lrr}
\hline \multirow{2}{*}{ Nutrients } & \multicolumn{2}{c}{ Species } \\
\cline { 2 - 3 } Organic Matter $\left(\mathrm{g} \mathrm{kg}^{-1}\right)$ & Gliricidia & Sabiá \\
$\mathrm{P}\left(\mathrm{mg} \mathrm{dm}^{-3}\right)$ & 10.46 & 8.43 \\
$\mathrm{~K}\left(\mathrm{mg} \mathrm{dm}^{-3}\right)$ & 3.85 & 3.95 \\
$\mathrm{Ca}\left(\mathrm{cmol}_{\mathrm{c}} \mathrm{dm}^{-3}\right)$ & 105.10 & 104.64 \\
$\mathrm{Mg}\left(\mathrm{cmol}_{\mathrm{c}} \mathrm{dm}^{-3}\right)$ & 2.68 & 2.91 \\
$\mathrm{Na}\left(\mathrm{mg} \mathrm{dm}^{-3}\right)$ & 1.11 & 0.93 \\
$\mathrm{pH}(\mathrm{em} \mathrm{água})$ & 14.56 & 13.94 \\
$\mathrm{H}+\mathrm{Al}\left(\mathrm{cmol}_{\mathrm{c}} \mathrm{dm}^{-3}\right)$ & 6.06 & 6.08 \\
\hline
\end{tabular}

There were no differences between species in the evaluated attributes

Table 2. Mean potassium content $\left(\mathrm{g} \mathrm{kg}^{-1}\right)$ in the litter of tree species at three years of age submitted to planting densities

\begin{tabular}{|c|c|c|c|c|c|c|}
\hline \multirow{2}{*}{ Species } & \multicolumn{5}{|c|}{ Planting density (x, plants ha $\left.{ }^{1}\right)$} & \multirow{2}{*}{$\begin{array}{c}\text { Regression equations } \\
(\mathrm{y}=\text { potassium content }, \mathrm{g} \mathrm{kg})\end{array}$} \\
\hline & 400 & 600 & 800 & 1,000 & 1,200 & \\
\hline Sabiá & $1.37 \mathrm{a}$ & $1.43 \mathrm{a}$ & $1.33 \mathrm{a}$ & $1.20 \mathrm{~b}$ & $1.47 \mathrm{a}$ & $y=1.36$ \\
\hline
\end{tabular}

Mean followed by the same letter in the columns do not differ at 0.05 probability level by the Tukey test. The parameters of the regression equations are significant at 0.1 probability level by Student's t-test

Table 3. Mean concentration of nutrients in litter of tree species at three years of age, submited to planting densities

\begin{tabular}{|c|c|c|c|c|c|c|}
\hline \multirow{2}{*}{$\begin{array}{c}\text { Nutrients } \\
\left(a^{-1 q^{-1}}\right)\end{array}$} & \multicolumn{5}{|c|}{ Planting density (plants ha') } & \multirow{2}{*}{ Regression equations } \\
\hline & 400 & 600 & 800 & 1000 & 1200 & \\
\hline $\mathrm{N}$ & 9.08 & 8.83 & 8.53 & 8.45 & 8.82 & $y^{2}=72.56+155860 x^{-2}, R^{2}=0.60$ \\
\hline$P$ & 0.28 & 0.28 & 0.25 & 0.30 & 0.25 & $y=0.27$ \\
\hline $\mathrm{Ca}$ & 30.82 & 33.77 & 34.00 & 32.30 & 32.85 & $y=32.75$ \\
\hline $\mathrm{Mg}$ & 4.75 & 3.97 & 4.10 & 3.97 & 3.85 & $y^{-1}=0.26-8192.83 x^{-2}, R^{2}=0.90$ \\
\hline
\end{tabular}

The parameters of the regression equations are significant at 0.1 probability level by Student's t-test 
Table 5. Average concentrations of soil nutrients under the crown of tree species, at three years of age, submitted to planting densities

\begin{tabular}{|c|c|c|c|c|c|c|}
\hline \multirow{2}{*}{ Nutrients } & \multicolumn{5}{|c|}{ Planting densities (plants ha') } & \multirow{2}{*}{ Regression equations ${ }^{1}$} \\
\hline & 400 & 600 & 800 & 1000 & 1200 & \\
\hline Org. Mat. $\left(\mathrm{g} \mathrm{kg}^{-1}\right)$ & 10.28 & 8.55 & 8.90 & 9.40 & 10.08 & $y=9.44$ \\
\hline$P\left(\mathrm{mg} \mathrm{dm}^{-3}\right)$ & 3.16 & 3.83 & 3.05 & 4.56 & 4.93 & $y^{2}=9.09+0.0000000086 x^{3}, R^{2}=0.71$ \\
\hline $\mathrm{K}\left(\mathrm{mg} \mathrm{dm^{-3 }}\right)$ & 105.23 & 104.07 & 98.41 & 109.67 & 106.99 & $y=104.87$ \\
\hline $\mathrm{Ca}\left(\mathrm{cmol}_{\mathrm{c}} \mathrm{dm}^{-3}\right)$ & 2.54 & 2.92 & 3.14 & 2.76 & 2.62 & $y=1.156+0.0047 x-0.0000029 x^{2}, R^{2}=0.83$ \\
\hline $\mathrm{Mg}\left(\mathrm{cmol}_{\mathrm{c}} \mathrm{dm}^{-3}\right)$ & 0.85 & 0.93 & 0.87 & 1.14 & 1.32 & $\mathrm{y}^{-1}=1.4487-0.00057 \mathrm{x}, \mathrm{R}^{2}=0.88$ \\
\hline $\mathrm{Na}\left(\mathrm{cmol}_{\mathrm{c}} \mathrm{dm}^{-3}\right)$ & 13.59 & 17.39 & 14.03 & 14.15 & 12.09 & $y^{-1}=0.14-95.01 x^{-1}+26,937.16 x^{-2}, R^{2}=0.86$ \\
\hline $\mathrm{pH}$ (water) & 6.00 & 6.08 & 6.09 & 6.02 & 6.15 & $y=6.07$ \\
\hline $\mathrm{H}+\mathrm{Al}\left(\mathrm{cmol}_{\mathrm{c}} \mathrm{dm}^{-3}\right)$ & 1.71 & 1.55 & 1.71 & 1.79 & 1.64 & $y=1.68$ \\
\hline
\end{tabular}

The parameters of the regression equations are significant at 0.1 level by Student's t-test

decreased. Ca content increased until the density of 800 plants $\mathrm{ha}^{-1}$ was reached, while $\mathrm{Na}$ content increased until the density reached approximately 567 plants ha ${ }^{-1}$.

In the discussion of the data relating to leaf litter (Tables 1-3) and to the soil (Tables 4 and 5) obtained in the present work, it is important to consider at least three interacting aspects which depend on environmental factors (soil and climate): competition between the trees of each species, competition from weeds and interaction with animals.

When planting density is relatively low, resources (water, light and nutrients) are left over for plant growth, and competition for these resources is relatively small. But as the planting density increases, the competition also increases, and plant growth tends to be less. There is therefore an optimal planting density, i.e. densities less than the optimal favor growth, and those greater than this optimal reduce growth. This has been demonstrated for trees, Rondon (2002) for example, in Schizolobium amazonicum (Huber) Ducke, and by Leite et al. (2011) in Eucalyptus grandis. The increase in planting density therefore increases competition for nutrients between plants, and reduces their availability to each plant. This explains the reduction in the $\mathrm{K}$ content for a given density (Table 1), and the reductions in the contents of $\mathrm{N}$ and $\mathrm{Mg}$ with increasing plant density, as observed in the present study (Table 3).

Wider spacing may favor the occurrence of weeds and consequently increase competition between them and the trees for light, water and nutrients. Souza et al. (2013) found that an increase in the planting density of gliricidia and thrush reduced the growth of weeds under the crown of both species. Besides the competition between trees, and between trees and weeds, the contribution of animals to the increase in soil nutrients should not be forgotten, as discussed below.

The effects of species on the nutrient content of the litter and soil were virtually the same. For the litter, the species differed only in $\mathrm{Mg}$ content (Table 1), while in the soil there was no difference in nutrient content between species (Table 5).

The effects of planting density on the nutrient content of the litter and soil were different (Tables 2, 3 and 5). For the litter, the increase in density only increased the concentration of $\mathrm{K}$ for gliricidia (Table 2). The content of the other elements in the litter was not changed or reduced (Table 3). In the soil, of the eight chemical attributes that were evaluated, the content increased in half of them (Table 5). This difference in the effects of planting density on the levels of elements in the soil and litter is most likely related to the greater amount of litter produced when the planting density increases. That is, the content of any one element in the litter may be low, but if the amount of litter deposited on the ground is high, the soil will receive a large quantity of that element.

Leite at al. (2011) found that an increase in planting density increased the amount of litter on the ground. In addition, Costa et al. (2004) found that nutrient uptake was correlated with the amount of litter that was deposited, including for gliricidia and sabiá. In other words, in the present study, although the element content remained unchanged or decreased (as a result of competition between trees), the increase in planting density may have provided an increase in the amount of litter per unit area, thus increasing the levels of various chemical properties of the soil.

When reclaiming degraded areas the plant-animal relationship is relevant. The use of plant species able to attract and maintain wildlife in implanted forests has proved of great value in accelerating plant succession, favoring those processes which are important for the sustainability of the forests, such as pollination and seed dispersal (Barbosa, 2006). It is likely that the increase in levels of some elements, which was seen in the soil under study (Table 6), are associated with animal waste interacting with the gliricidia and sabiá plants, or with animals which died in the area in which these species were grown. There is a possibility of the animals having a preference for the denser plants, in order to guarantee themselves more protection. Under the higher plant densities therefore, more animal waste would accumulate which would in turn make the soil rich in nutrients.

Leite et al. (2011) found that out of ten nutrients evaluated, planting density affected only the levels of $\mathrm{K}$ and $\mathrm{Mg}$ in the leaves. Moreira et al. (2007) found that of 12 nutrients, an increase in planting density only reduced the levels of boron. Mallik et al. (2008) concluded that the effects of tree species are far more important than the effects due to spacing on the properties of forest soils.

On the other hand, Pavan et al. (1999) found that increasing planting density in the coffee tree increased the $\mathrm{pH}$, the exchangeable $\mathrm{Ca}, \mathrm{Mg}$ and $\mathrm{K}$, the extractable $\mathrm{P}$, the levels of organic $\mathrm{C}$ and the water content of the soil, as well as reduced the levels of exchangeable Al. In the study of Pavan et al. (1999), the highest planting density $\left(7,143\right.$ plants ha $\left.{ }^{-1}\right)$ was nearly eight 
times the lowest that was tested (893 plants ha-1). With forest species, especially in timber production, very high ranges across densities can not be evaluated. Very high densities can result in lower yields of wood, and even in the death of trees due to competition, resulting therefore in the loss of time, labour and resources.

The ideal planting density of a species will depend on the intended use of that species (Oliveira Neto et al., 2003). The range of planting densities evaluated in forest species can be relatively large under special situations. Karim \& Savill (1991) for example, tested planting densities of 1,250-20,000 gliricidia plants ha-1. However, their goal was to evaluate the initial growth of that species under alley cropping.

But in general, the range of those planting densities, evaluated in forest experiments for the production of timber, is relatively small, and it therefore becomes more difficult to detect significant differences in their effects on the characteristics of the soil. Furthermore, the use of large plots (due to the low densities) reduces local control and increases problems of soil sampling, resulting in lower experimental accuracy. Indeed, this may explain the high values of the experimental coefficient of variation which was obtained in the present study.

\section{Conclusions}

1. The magnesium content in the gliricidia leaf litter was higher than that from the sabiá. There were no differences between species for the content of other elements.

2. The increase in planting density resulted in a decrease in the nitrogen and magnesium content, but did not alter the levels of calcium and phosphorus in the leaf litter.

3. The amounts of nutrient content in the leaf litter of both species presented the sequence calcium $>$ nitrogen $>$ magnesium $>$ potassium $>$ phosphorus.

4. There was no difference in soil fertility between the soils cultivated with the two species.

5. Increased density raised the levels of phosphorus and magnesium in the soil. The sodium and calcium content increased and then decreased with the increasing density. There was no effect of density on the organic matter, potassium, $\mathrm{pH}$ or potential acidity.

\section{Literature Cited}

Barbosa, K. C. Importância da interação animal-planta na recuperação de áreas degradadas. In: Barbosa, L. M. (coord.). Manual para recuperação de áreas degradadas do estado de São Paulo: Matas ciliares do interior Paulista. São Paulo: Instituto de Botânica, 2006. 128p.

Carmo Filho, F.; Oliveira, O. F. Mossoró: um município do semi-árido nordestino. Mossoró: Fundação Guimarães Duque/ESAM, 1989. 62p.

Casteleti, C. H. M.; Santos, A. M. M.; Tabarelli, M.; Silva, J. M. C. Quanto ainda resta da Caatinga? Uma estimativa preliminar. In: Leal, L.R.; Tabarelli, M.; Silva, J. M. C. Ecologia e conservação da Caatinga. Recife: UFPE, 2003. p.719-734.
Costa, G. S.; Franco, A. A.; Damasceno, R. N.; Faria, S. M. Aporte de nutrientes pela serrapilheira em áreas degradada e revegetada com leguminosas arbóreas. Revista Brasileira de Ciência do Solo, v.28, p.919-927, 2004.

Duarte, R. M. R.; Casagrande, J. C. A interação solo-planta na recuperação de áreas degradadas. In: Barbosa, L. M. (coord.). Manual para recuperação de áreas degradadas do estado de São Paulo: Matas ciliares do interior paulista. São Paulo: Instituto de Botânica, 2006. p.52-69.

EMBRAPA - Empresa Brasileira de Pesquisa Agropecuária. Manual de métodos de análise de solo, Rio de Janeiro: EMBRAPA, 1997. 212p.

EMBRAPA - Empresa Brasileira de Pesquisa Agropecuária. Centro Nacional de Pesquisa do Solo. Sistema brasileiro de classificação de solos. Brasília: Serviço de Produção de Informação, 2006. 306p.

Galindo, I. C. L.; Ribeiro, M. R.; Santos, M. F. A.V.; Lima, J. F. W. F.; Ferreira, R. F. A. Relações solo-vegetação em áreas sob processo de desertificação no município de Jataúba-PE. Revista Brasileira de Ciência do Solo, v.32, p.1283-1296, 2008.

Karim, A. B.; Savill, P. S. Effect of spacing on growth and biomass production of Gliricidia sepium (Jacq) Walp. in an alley cropping system in Sierra Leone. Agroforestry Systems, v.16, p.213-222, 1991.

Leite, F. P.; Silva, I. R.; Novais, R. F.; Barros, N. F.; Neves, J. C.; Villani, E. M. A. Nutrient relations during an Eucalyptus cycle at different populations densities. Revista Brasileira de Ciência do Solo, v.35, p.949-959, 2011.

Mallik, A. U.; Hossain, M. K.; Lamb, E. G. Species and spacing effects of Northern conifers on forest productivity and soil chemistry in a 50-year-old common garden experiment. Journal of Forestry, v.106, p.83-90, 2008.

Mendonça, A. V. R.; Carneiro, A. V. R.; Barroso, D. G.; Santiago, A. R.; Freitas, T. A. S.; Souza, J. S. Desempenho de quatro espécies de Eucalyptus spp em plantios puros e consorciados com sabiá (Mimosa caesalpiniaefolia Benth) em cava de extração de argila. Revista Árvore, v.32, p.395-405, 2008.

Moreira, A.; Heinrich, R.; Pereira, J. C. R. Densidade de plantio na produtividade e nos teores de nutrientes nas folhas e frutos da bananeira cv. Thap Maeo. Revista Brasileira de Fruticultura, v.29, p.626-631, 2007.

Oliveira Neto, S. N.; Reis, G. G.; Reis, M. G. F.; Neves, J. C. L. Produção e distribuição de biomassa em Eucalyptus camaldulensis Dehn. Em resposta à adubação e ao espaçamento. Revista Árvore, v.27, p.15-23, 2003.

Pavan, M. A.; Chaves, J. C. D.; Siqueira, R.; Androcioli Filho, A.; Corazzi Filho, A.; Balota, E. L. High coffee population density to improve fertility of an oxisol. Pesquisa Agropecuária Brasileira, v.34, p.459-465, 1999.

Pereira, F. G. C. Atributos de qualidade física e química de um Latossolo Amarelo submetido a diferentes usos no semiárido Baiano. Cruz das Almas: UFRB, 2010. 67p. Dissertação Mestrado 
Rangel, O. J. P.; Silva, C. A.; Guimarães, T. G.; Melo, L. C. A.; Oliveira Júnior, A. C. Carbono orgânico e nitrogênio total do solo e suas relações com os espaçamentos de plantio de cafeeiro. Revista Brasileira de Ciência do Solo, v.32, p.20512059, 2008.

Rondon, E. V. Produção de biomassa e crescimento de árvores de Schizolobium amazonicum (Huber) Ducke sob diferentes espaçamentos na região de mata. Revista Árvore, v.26, p.573-576, 2002.

Souza, A. D.; Silva, P. S. L.; Oliveira, O. F.; Dantas, I. M.; Morais, P. L. D. Weeds under the canopies of tree species submitted to different planting densities and intercropping. Planta Daninha, v.31, p.29-37, 2013.
Vezzani, F. M.; Tedesco, M. J.; Barros, N. F. Alterações dos nutrientes no solo e nas plantas em consórcio de eucalipto e acácia negra. Revista Brasileira de Ciência do Solo, v.25, p.225-231, 2001.

Vieira, M.; Caldato, S. L.; Rosa, S. F.; Kanieski, M. R.; Araldi, D. B.; Santos, S. R.; Schumacher, M. V. Nutrientes na serrapilheiran em fragmento de floresta estacional decidual, Itaara, RS. Ciência Florestal, v.20, p.611-619, 2010.

Vivanco, L.; Austin, A. T. Tree species identity alters forest litter decomposition through long-term plant and soil interactions in Patagonia, Argentina. Journal of Ecology, v.96, p.727-736, 2008. 